\title{
JESZCZE RAZ O POCZĄTKACH BRACTWA SZKAPLERZNEGO W KRAKOWIE
}

W tomie 4-5 „F. H. C.” o. Benignus Józef Wanat zamieścił rozprawę „Kult Matki Bożej w klasztorze O.O. Karmelitów na Piasku w Krakowie. Na str. 202 był łaskaw cytować mój pogląd z pracy „Fundacja klasztoru karmelitów trzewiczkowych na Piasku w Krakowie" (Nasza Przeszłość, t. 60, 1983, s. 118-119) na temat dokumentu z 1411 r., w którym generał zakonu przyjmował rajców Krakowa do bractwa zakonnego oraz udziału w łaskach i dobrach duchowych zakonu. Rzeczywiście, domniemywałem wtedy powstanie na skutek tego aktu bractwa szkaplerznego w Krakowie. W swej książce „U zarania karmelitów w Polsce" (Warszawa 1993, s. 132, 135) dałem jednak wyraz odmiennemu przekonaniu. Sądzę obecnie, że w r. 1411 powstało w Krakowie typowe bractwo karmelitańskie o profilu maryjnym, grupujące krakowską elitę, na wzór licznych podobnych instytucji znanych wtedy w Anglii, Francji czy Portugalii. Nie było to jednak bractwo szkaplerzne. Karmelici już w XIV w. Posługiwali się symboliką i właściwościami duchowymi szkaplerza. Znamy sporo przykładów przyjmowania wtedy szkaplerza na całe życie po spełnieniu oczekiwań wotywnych przez osoby z najwyższych kręgów hierarchii społecznej, pozostające w promieniu oddziaływania dewocyjnej formacji karmelitów. Jednak propagowanie szkaplerza jako instrumentu kultu masowego następuje dopiero około połowy XV stulecia. Poprzedza je ustanowienie zakonnego święta "Commemoratio solemnis sanctas Mariae" w dniu 17 lipca (pierwsza wzmianka w r. 1386).

$\mathrm{Z}$ tego też powodu wyraziłem przekonanie, że w epoce Jagiełly nie mogło jeszcze dojść do instalacji bractw szkaplerznych przy pierwszych fundacjach klasztorów karmelitańskich. Co do konwentu krakowskiego, posiadane przez nas informacje źródłowe sugerują erekcję bractwa szkaplerznego dopiero w XVI w. 